\title{
Uterine Corpus Adenosarcoma pT1c TNM
} Finding v8

National Cancer Institute

\section{Source}

National Cancer Institute. Uterine Corpus Adenosarcoma pT 1c TNM Finding v8. NCI

Thesaurus. Code C139856.

Uterine corpus adenosarcoma with tumor invading more than half of the myometrium.

(from AJCC 8th Ed.) 